\title{
Wartości codzienne i podstawowe w świadomości młodzieży maturalnej w Putawach
}

W socjologii wyróżnia się wartości codzienne, ostateczne i podstawowe, przy czym każdy z tych porządków jest zróżnicowany i zindywidualizowany. Orientacja na wartości ostateczne ma charakter religijny lub pozareligijny. W pierwszym przypadku cele ostateczne, jakie jednostka sobie stawia, są związane z sacrum (Bóg, Siła Wyższa, Nadprzyrodzoność itp.), w drugim zaś z dążeniami należącymi do sfery profanum (wartości humanistyczne), którym przypisuje się szersze funkcje w sensie ich absolutyzowania. Wartości ostateczne określają stan finalny ludzkich aspiracji, dążeń i działań. Wartości ostateczne uznawane przez niewierzących nie mają odniesień do Transcendencji, są to wartości ze sfery profanum, traktowane jako ostateczne, dostarczające sensu oraz identyczności osobowej. W warunkach sekularyzacji, promującej postawy racjonalne i z „tego świata”, tracą na znaczeniu religijne orientacje na wartości ostateczne.

Wartości podstawowe są niezbędne dla rozwoju człowieka i społeczeństwa oraz stanowią fundament porozumienia i działania społecznego, co więcej - tworzą normatywny etos jednoczący wszystkie siły społeczeństwa do realizacji dobra wspólnego. Wśród wartości podstawowych wymienia się najczęściej: wolność, życie (także nienarodzonych), równość, sprawiedliwość, prawdę, miłość, solidarność, pokój, patriotyzm, tolerancję. Wszystkie one zawierają treści, które streszczają się w godności ludzkiej, umożliwiającej fundamentalny konsens i ujednolicony etos. W odniesieniu do wartości podstawowych nie chodzi o spełnienie pragnień poszczególnych jednostek, które są różne i zmienne, ale o wartości, bez których nie może istnieć społeczeństwo, i które są (lub powinny być) przedmiotem troski i zabiegów ludzkich, niezależnie od ich indywidualnych uzdolnień, interesów i preferencji ${ }^{1}$.

W. Piwowarski, ABC katolickiej nauki społecznej, cz. I, Wprowadzenie, podstawy, kierunki, Wydawnictwo Diecezjalne, Pelplin 1993, s. 73-77; J. Mariański, Wartości osobowe i społeczne, [w:] Encyklopedia aksjologii pedagogicznej, red. K. Chałas, A. Maj, POLWEN Polskie Wydawnictwo Encyklopedyczne, Radom 2016, s. 1266-1269. 
Wartości codzienne - w przeciwieństwie do wolno zmieniających się wartości podstawowych i ostatecznych - ulegają dość szybkim przemianom, w miarę jak zmieniają się indywidualne cele i dążenia życiowe. Relatywność wartości codziennych nie przekreśla istnienia wartości absolutnych czy uniwersalnych. Jedne z wartości codziennych koncentrują się na jednostce i mają charakter intrapersonalny (wartości osobowe), drugie są zwrócone ku innym ludziom i mają charakter interpersonalny (wartości społeczne). Wartości codzienne o charakterze względnym zyskują na ważności w powiązaniu z wartościami ostatecznymi, tracą zaś na znaczeniu w warunkach przyspieszonych zmian (tzw. akceleracja przemian wartości). Niekiedy angażują jednostki nawet do tego stopnia, że są one zdolne oddać życie w ich obronie.

W niniejszym artykule zostaną omówione wybrane wartości uznawane przez maturzystów puławskich. W głównej hipotezie roboczej zakładamy, że młodzież maturalna znajduje się w fazie zaawansowanej młodości, częściowo uniezależnia się od rodziny pochodzenia, jej główne zainteresowania i działania przenoszą się poza rodzinę. Rozpoznaje ona już dokładnie swe perspektywy życiowe, a równocześnie coraz wyraźniej ustala swoją hierarchię wartości i autonomię moralną. Następuje także zachwianie, a niekiedy też rozpad ukształtowanych w rodzinie wartości i norm, które w coraz mniejszym stopniu wpływają na postępowanie jednostek. Młodzież maturalna szczególnie przeżywa kryzys tożsamości, w tym także kryzys tożsamości religijnej oraz moralnej. Wartości religijne i moralne stają się kwestią wyboru i wykazują się brakiem stabilizacji w czasie, a także swoistą ambiwalencją. Jest to „cena”, jaką płacą jednostki w warunkach radykalnych zmian społecznych. Nowoczesne społeczeństwa zindywidualizowane i spluralizowane charakteryzują się różnorodnością celów życiowych, akceptowanych norm, światopoglądów i stylów życia. Brakuje konsensu w odniesieniu do wspólnie uznawanych wartości oraz ich hierarchii.

Ankietę audytoryjną przeprowadzono w czterech szkołach ponadgimnazjalnych w Puławach (w I Liceum Ogólnokształcącym im. księcia Adama Czartoryskiego, w Społecznym Liceum Ogólnokształcącym im. Christiana Piotra Aignera, w Technikum nr 1 i w Technikum nr 2). Do dalszych analiz statystyczno-korelacyjnych w roku 2016 włączono 286 kwestionariuszy ankiet, co stanowiło 83,6\% założonej próby badanej. Narzędziem badawczym był kwestionariusz ankiety pt. Maturzyści a wartości moralne, opracowany w roku 1993 w Katedrze Socjologii Moralności KUL, wzbogacony w 2009 r. o kilka dodatkowych pytań. W czterech szkołach ponadgimnazjalnych kilkanaście osób nie wypełniło kwestionariusza lub wypełniło go tylko częściowo, inni byli - mimo ponawianych prób dotarcia do nich - nieosiągalni (w sumie 16,4\%). 
W całej zbadanej zbiorowości było więcej kobiet niż mężczyzn (58,7 wobec 41,3\%); młodzieży z liceów ogólnokształcących mniej niż młodzieży z techników (48,3 wobec 51,7\%); młodzieży ze wsi i z miast do 20 tys. mieszkańców więcej niż młodzieży z Puław (61,9 wobec 38,1\%); młodzieży z rodzin inteligenckich $(31,5 \%)$ i robotniczych $(26,9 \%)$ więcej niż z rodzin chłopskich $(14,3 \% ; 2,8 \%$ - inne określenia, 24,5\% - brak odpowiedzi); określających sytuację materialną swojej rodziny jako dość dobrą (39,2\%) i przeciętną (32,5\%) więcej niż jako wyraźnie dobrą (19,2\%) lub złą (5,6\%; 3,5\% - brak odpowiedzi). Wśród ogółu zbadanych maturzystów puławskich 5,9\% określiło siebie jako głęboko wierzących, 55,9\% - jako wierzących, 16,8\% - jako niezdecydowanych w sprawach wiary, 10,8\% - jako obojętnych religijnie, 9,4\% - jako niewierzących i 1,2\% - brak odpowiedzi; 9,4\% - to uczestniczący w każdą niedzielę we mszy św., a niekiedy i częściej, 15,0\% - w każdą niedzielę, 27,9\% - od jednego do trzech razy w miesiącu, 27,3\% - kilka razy w roku, 18,9\% - w ogóle niepraktykujący i 1,4\% - to nieudzielający odpowiedzi ${ }^{2}$.

W warunkach intensywnej transformacji społeczno-ekonomicznej i społeczno-kulturowej zmienia się ważność i znaczenie poszczególnych wartości i ich treści, zmieniają się też praktyczne sposoby ich realizacji. Niektóre wartości całkowicie stabilne w osobowości człowieka mogą okazać się trudne do realizacji w życiu codziennym, a nawet stają się dysfunkcjonalne w zróżnicowanym i zmieniającym się radykalnie społeczeństwie. W nowych warunkach ustrojowych, gospodarczych, społecznych i kulturowych zaznaczają się szczególnie silne tendencje w kierunku indywidualizmu, wzrostu znaczenia wartości skoncentrowanych na ,ja”. Przemiany aksjologiczne ku indywidualizmowi wiążą się z różnymi motywacjami. Tak rozumiane wartości są zmienne, relatywne, a nawet relatywistyczne. Są one zakorzenione w procesach wartościowania, nie mają odniesienia do wartości obiektywnych ${ }^{3}$.

\section{RODZINA JAKO WARTOŚĆ NACZELNA}

Rodzina pośredniczy między jednostką i społeczeństwem w zakresie przekazywania, percepcji i akceptacji treści kulturowych. Wśród przekazywanych wartości kulturowych są też te, które w jakiś sposób definiują co jest dobre, a co złe. Przed rokiem 1989 mówiło się nawet o niechęci do zbiorowych form życia społecznego, o jego prywatyzacji, co prze-

J. Mariański, Religijność maturzystów puławskich w procesie przemian, „Zeszyty Naukowe KUL” 2017, nr 2 (60), s. $225-252$.

R. Spaemann, Kroki poza siebie. Przemówienia i eseje, Oficyna Naukowa, Warszawa 2012, s. 251. 
jawiało się m.in. w tendencji do zamykania się w kręgu spraw rodzinnych, do swoistej ucieczki w życie rodzinne. Rodzina była miejscem schronienia przed agresją i zewnętrznym zagrożeniem, grupą społeczną dającą poczucie bezpieczeństwa i oparcia w życiu, a także przestrzenią, w której człowiek jest akceptowany takim, jakim jest, i może rozwijać się osobowościowo. Orientacja na rodzinę jako instytucję koncentrującą ludzkie potrzeby i dążenia życiowe mogła mieć do pewnego stopnia charakter kompensacyjny i ucieczkowy (rodzina jako bezpieczny azyl).

Wszyscy zgadzają się co do tego, że rodzina - jakkolwiek nie jest jedynym czynnikiem podtrzymywania ciągłości dziedzictwa społecznego, kulturowego, moralnego i religijnego - jest jedną z najważniejszych instancji wychowawczych i nośników socjalizacji. Przekazuje ona nie tylko określony zasób wiedzy, ale i pewien system wartości, dążeń i aspiracji życiowych. W niej najskuteczniej weryfikuje się świat wartości i ich synteza. Rodzina otwiera się na społeczeństwo i w nim musi znaleźć swoje oparcie zarówno w formie uznania społecznego, jak i niezbędnej pomocy ekonomicznej, by mogła odegrać w nim swoją niezastąpioną rolę w tworzeniu klimatu bezpieczeństwa oraz zaufania, aby dzieci mogły spokojnie patrzeć w przyszłość, a także otrzymać właściwe wychowanie. Rodzina i szczęśliwe życie rodzinne w latach dziewięćdziesiątych XX w. znajdowały się na pierwszym miejscu wśród celów życiowych Polaków ${ }^{4}$.

Badanym maturzystom przedstawiono do oceny następujące wartości: praca, rodzina, zdrowie, przyjaciele i znajomi, moralność, czas wolny, polityka, dobra materialne i religia. Znaczenie, jakie przywiązują badani w swoim życiu do tych wartości, oceniają według następującej skali: bardzo ważne, raczej ważne, niezbyt ważne, w ogóle nieważne, trudno powiedzieć. Zestaw ocenianych wartości został zdominowany przez wartości codzienne, o charakterze konkretnym. Jedynie wartość „,religia” należy do innego porządku aksjologicznego, jest wartością ostateczną, nadającą sens ludzkiemu życiu.

W całej zbiorowości maturzystów puławskich 41,6\% badanych uznawało pracę za wartość bardzo ważną w swoim życiu, 48,3\% - za raczej ważną, 3,8\% - za niezbyt ważną, $0,0 \%$ - za w ogóle nieważną, 5,6\% odpowiedziało - trudno powiedzieć, $0,7 \%$ - nie udzieliło odpowiedzi; rodzina (odpowiednio) - 87,1\%, 6,3\%, 1,0\%, 0,3\%, 4,5\%, $0,7 \%$; przyjaciele i znajomi - 60,1\%, 32,2\%, 3,5\%, 0,0\%, 3,8\%, 0,3\%; czas wolny - 29,7\%, $53,8 \%, 8,4 \%, 0,7 \%, 6,3 \%, 1,0 \%$; polityka - 5,2\%, 18,9\%, 40,2\%, 25,2\%, 10,1\%, 0,3\%; religia $-28,3 \%, 38,5 \%, 14,3 \%, 9,8 \%, 7,7 \%, 1,4 \%$; zdrowie - 75,5\%, 17,8\%, 0,7\%, 0,7\%, 4,2\%,

\footnotetext{
R. Boguszewski, Współczesne znaczenie i rozumienie rodziny w Polsce, „Zeszyty Naukowe KUL” 2015, nr 4 (58), s. 127-148.
} 
1,0\%; moralność - 48,6\%,37,1\%,6,6\%, 0,7\%,6,3\%, 0,7\%; dobra materialne - 20,6\%, 47,6\%, 22,7\%, 1,4\%, 7,0\%, 0,7\% (wskaźnik przeciętny dla odpowiedzi „bardzo ważne” i „raczej ważne” - 77,5\%; wskaźnik przeciętny odpowiedzi „bardzo ważne” - 44,1\%).

Biorąc pod uwagę najwyższe oceny („bardzo ważne”) i oceny średnie („raczej ważne”) można stwierdzić, że wśród maturzystów puławskich większe lub mniejsze znaczenie przywiązuje się do następujących wartości: rodzina (93,4\%), zdrowie $(93,3 \%)$, znajomi i przyjaciele $(92,3 \%)$, praca $(89,9 \%)$, moralność $(85,7 \%)$, czas wolny $(83,5 \%)$, dobra materialne $(68,2 \%)$, religia $(66,8 \%)$ i polityka $(24,1 \%)$. Kolejność wartości wybieranych według najwyższej oceny („bardzo ważne”) jest bardzo podobna, ale stopień aprobaty rodziny jest wyraźnie wyższy niż pozostałych wartości. Znamienne jest to, że przyjaciół i znajomych, moralność, pracę, czas wolny, a nawet dobra materialne ceni się wyżej niż religię. Trzy najwyższe wartości: rodzina, zdrowie, przyjaciele i znajomi uzyskały ponad $90 \%$ ogólnej aprobaty ${ }^{5}$.

Dokonywane wybory wartości koncentrują się w obszarze dwóch ocen - „bardzo ważne” i „raczej ważne”. Tylko nieliczni respondenci stosowali do określenia znaczenia wartości ocenę „,niezbyt ważne”, „w ogóle nieważne” lub wstrzymywali się od wyrażenia jednoznacznej opinii. Badani maturzyści w znacznej mierze akceptują wartości życia codziennego, zwłaszcza te, które wiążą się z poszukiwaniem zabezpieczenia emocjonalnego i prywatnością, a także z pragnieniem urządzenia się według własnych wyobrażeń. Wartości ostateczne (religia) odgrywają rolę do pewnego stopnia drugoplanową. Maturzyści pragną żyć życiem rodzinnym, spokojnym i ustabilizowanym, w gronie przyjaciół, z dala od wielkiej polityki.

Nieco wyższe wyniki uzyskano w roku szkolnym 2009/2010 wśród maturzystów lubelskich. Biorąc łącznie pod uwagę najwyższe oceny („bardzo ważne”) i oceny średnie („raczej ważne”) skonstatowano, że rodzinę aprobowało $97,1 \%$ badanych, zdrowie - 95,4\%, przyjaciół i znajomych - 95,4\%, pracę - 92,1\%, moralność - 90,5\%, czas wolny - 79,9\%, religię - 78,2\%, dobra materialne - 76,0\% i politykę - 15,7\% (wskaźnik przeciętny - 80,0\%; wskaźnik przeciętny tylko dla odpowiedzi „bardzo ważne” - 45,1\%) ${ }^{6}$. We wcześniejszych badaniach socjologicznych zrealizowanych przez Emilię Żerel w Lublinie w roku 2005 92,9\% badanych uznało pracę za wartość bardzo ważną lub raczej ważną,

W. Romanowicz, Podstawowe wartości młodzieży prawosławnej, „Rozprawy Społeczne” 2014, nr 2 (8), s. $25-26$.

6 M. Rola, Wartości moralne w świadomości maturzystów lubelskich. Studium socjologiczne, Drukarnia Standruk, Lublin 2016, s. 280-282; P. Wójcik, System wartości deklarowanych przez maturzystów liceów ogólnokształcacych województwa warmińsko-mazurskiego w kontekście nauki Kościoła katolickiego. Informacja o badaniu, „Societas/Communitas” 2014, nr 1, s. 169-194. 
rodzinę - 93,8\%, przyjaciół i znajomych - 93,4\%, czas wolny - 79,5\%, religię - 76,1\%, politykę - 23,2\% (wskaźnik przeciętny - 76,5\%; wskaźniki przeciętny tylko dla odpowiedzi „bardzo ważne” - 46,2\%).

W roku 2016 wśród maturzystów puławskich kobiety ceniły nieco wyżej niż mężczyźni (według oceny „bardzo ważne”) pracę (44,0 wobec 38,1\%), rodzinę (89,9 wobec 83,1\%), przyjaciół i znajomych $(64,9$ wobec $53,4 \%)$, czas wolny $(29,9$ wobec $29,7 \%)$, politykę ( 8,0 wobec $2,7 \%)$, religię ( 35,1 wobec $18,6 \%)$, zdrowie $(77,4$ wobec $72,9 \%)$ i dobra materialne (21,4 wobec 19,5\%). Mężczyźni nieco częściej niż kobiety doceniali moralność (50,8 wobec 47,0\%). Ze względu na typ szkoły można zauważyć, że młodzież licealna wyżej niż młodzież z techników ceni takie wartości, jak: polityka $(8,0$ wobec $2,7 \%)$ i moralność $(49,6$ wobec 48,6\%). Młodzież z techników bardziej docenia pracę (54,1 wobec $28,3 \%$ ), rodzinę (92,6 wobec $81,2 \%)$, przyjaciół i znajomych $(64,2$ wobec $55,8 \%)$, czas wolny $(35,8$ wobec $23,2 \%)$, religię $(31,8$ wobec $24,6 \%)$, zdrowie $(83,1$ wobec $67,4 \%)$ i dobra materialne $(25,7$ wobec $15,2 \%)$.

Biorąc pod uwagę środowisko terytorialne, konstatujemy prawidłowość, że im bardziej zamknięte jest środowisko społeczne, tym wyższa jest aprobata wartości: praca (wieś i miasta do 20 tys. mieszkańców - 45,2\%, Puławy - 35,1\%), rodzina (91,0 wobec 80,7\%), przyjaciele i znajomi $(65,0$ wobec $52,3 \%)$, czas wolny $(32,8$ wobec $24,8 \%)$, religia $(33,9$ wobec $19,3 \%)$, zdrowie $(81,9$ wobec $65,1 \%)$, dobra materialne $(22,0$ wobec $18,3 \%)$ oraz mniejsza w przypadku takich wartości, jak polityka (4,0 wobec $7,3 \%)$ i moralność (46,9 wobec 51,4\%).

Struktura autoidentyfikacji religijnych wpływa na zróżnicowanie znaczenia niektórych wartości. Im wyższa jest religijność, tym większe znaczenie jest przypisywane takim wartościom, jak: praca (wierzący 41,2\%, niewierzący - 40,7\%), rodzina $(92,1$ wobec $74,1 \%)$, przyjaciele i znajomi $(65,1$ wobec $48,1 \%)$, religia $(42,9$ wobec $0,0 \%)$, zdrowie (82,5 wobec $63,0 \%)$, niższe zaś, gdy chodzi o czas wolny (26,0 wobec $44,4 \%)$, politykę $(5,1$ wobec $11,1 \%)$, moralność $(47,5$ wobec $63,0 \%)$ i dobra materialne $(18,1$ wobec $22,2 \%)$. W podobnym kierunku oddziałuje zmienna niezależna „praktyki religijne”. Uczęszczający do kościoła w każdą niedzielę lub niekiedy i w dni powszednie częściej niż w ogóle niepraktykujący doceniają: rodzinę ( 87,1 wobec $75,9 \%)$, religię (50,0 wobec $3,7 \%$ ), zdrowie (74,3 wobec 54,8\%), rzadziej zaś dobra materialne (14,8 wobec $20,0 \%)$, pracę (32,9 wobec $42,6 \%)$, przyjaciół i znajomych $(24,3$ wobec $38,9 \%)$, moralność (44,3 wobec $57,4 \%)$ i politykę $(4,5 \text { wobec } 5,6 \%)^{7}$.

E. Budzyńska, Międzypokoleniowe więzi w rodzinie. Studium socjologiczne rodzin polskich i słowackich, Wydawnictwo UŚ, Katowice 2018, s. 359-387; T. Bajkowski, U źródeł tożsamości rodzinnej. System rodzinny w percepcji młodzieży akademickiej, Wydawnictwo Naukowe SCHOLAR, Warszawa 2018. 
Cechy demograficzne nie różnicują wagi przywiązywanej do poszczególnych wartości w bardzo wyraźnym stopniu. Ogólnie można powiedzieć, że kobiety nieco częściej niż mężczyźni pozytywnie oceniały większość z dziewięciu wartości, młodzież szkół technicznych robiła to częściej niż młodzież z liceów ogólnokształcących, młodzież mieszkająca na wsi lub w małych miastach częściej niż mieszkająca w Puławach. Wartościami najwyższymi we wszystkich kategoriach demograficznych i społecznych są rodzina i zdrowie, najniższą zaś polityka. Nisko jest również lokowana w hierarchii wartości religia, ale wyższa religijność sprzyja aprobacie takich wartości, jak rodzina, przyjaciele i znajomi oraz zdrowie. Niewierzący, a także w ogóle niepraktykujący większe znaczenie przypisują takim wartościom, jak: czas wolny, polityka, moralność i wartości materialne ${ }^{8}$.

Rodzina jest uznawana przez zdecydowaną większość maturzystów puławskich. Jeżeli weźmiemy pod uwagę oceny najwyższe („bardzo ważne”), to różnica w akceptacji pomiędzy rodziną a pozostałymi wartościami jest wyraźna. Według ocen „bardzo ważne” i „raczej ważne” różnice między wartością rodzina i wartościami praca, przyjaciele i znajomi, a nawet czas wolny są już mniej znaczące. Wyraźnie niżej jest oceniana religia i polityka. Warto zauważyć, że hierarchia wartości: od rodziny do polityki, jest w Polsce podobna do tej, jaką konstatuje się w innych krajach europejskich, w Polsce jednak wyższy jest stopień akceptacji tych wartości ${ }^{9}$.

Przeprowadzone badania socjologiczne wśród maturzystów puławskich potwierdzają trwałą obecność „orientacji na rodzinę” w świadomości młodzieży.

W okresie transformacji systemowej te więzi rodzinne i przyjacielskie ciągle stanowią - mimo wszystko - wielką wartość dla Polaków. Poziom satysfakcji z życia rodzinnego i towarzyskiego jest nadal - jak wynika z różnych badań socjologicznych - wysoki i znów, jak wiele razy w przeszłości, grupy te pomagają przetrwać różne zmiany społeczne, „oswoić” się z nową rzeczywistością okresu transformacji. Rodzina stanowi dla nas podstawowe środowisko działania i samorealizacji, a satysfakcjonujące życie rodzinne staje się najważniejszą wartością i celem Polaków na początku XXI wieku' ${ }^{10}$.

8 A. Górny, Religia i rodzina jako fundament świata wartości współczesnej rodziny ślaskiej, [w:] Młodzi w społeczeństwie zmiany. Studia polsko-ukraińskie, red. M. Sroczyńska, J. Paczkowski, Wyższa Szkoła Umiejętności, Kielce 2010, s. 273-278; K. Szafraniec, Młodość jako wyłaniający się problem i nowa polityczna siła, „Nauka” 2010, nr 1, s. 101-122.

9 U. Hamachers-Zuba, E. Lehner, C. Tschipan, Partnerschaft, Familie und Geschlechterverhältnisse in Österreich, [w:] Die Österreicher/-innen. Wertewandel 1990-2008, Hrsg. C. Friesl, U. Hamachers-Zuba, R. Polak, Czernin Verlag, Wien 2009, s. 128; T. Biernat, Małżeństwo i rodzina w opiniach młodych Polaków, Niemców i Hiszpanów, „Kultura i Edukacja” 2009, nr 2, s. 71-87.

10 J. Szymczyk, Przemiany wartości Polaków. Wybrane aspekty i tendencje, [w:] Społeczne i etyczne aspekty rozwoju społecznego, red. W. Jedynak, J. Kinal, URz, Rzeszów 2015, s. 25-26. 


\section{WARTOŚCI CODZIENNE W OPINII MATURZYSTÓW PUŁAWSKICH}

Wartości codzienne są często utożsamiane z celami i dążeniami życiowymi. Są odnoszone do pewnych przedmiotów lub stanów rzeczy, które zaspokajają potrzeby jednostek bądź grup społecznych. „Jeśli ludzie uznają jakieś ważne dobra za bardziej od innych warte tego, aby je w życiu osiągnąć, to mówi się, że ludzie uznają je za wartości życiowe"11. W rzeczywistości wartości są czymś więcej niż potrzebami, celami życiowymi, aspiracjami i dążeniami, chociaż zawierają w sobie te wszystkie elementy. Wartości są relatywnie bardziej stabilne, głębiej zakotwiczone w strukturze osobowości jednostki. Ich realnym przejawem są cele i dążenia życiowe, mobilizujące do aktywności codziennej, zwłaszcza w sytuacjach trudnych. Przyczyniają się do nadania osobom i grupom społecznym konkretnych kształtów i identyczności.

Wartości rozumiane jako cele i dążenia życiowe mają swoje odniesienia nie tylko do świadomości ludzi, ale i do działań realizowanych w zmieniających się warunkach społeczno-kulturowych (wartości nie są jedynie rezultatem czy funkcją stosunków społecznych i ekonomicznych). Oddziałują one wyraźniej, jeżeli są podzielane przez znaczące grupy społeczne, mają wówczas niezwykłą siłę motywacyjną wobec działań jednostkowych i zbiorowych. Przekonanie, że „coś” ma istotną wartość, może być ważnym czynnikiem motywującym do działania. Wartości i normy jako części składowe reguł społecznych wyznaczają działanie instytucji i stanowią części składowe kultury ${ }^{12}$.

Ważną kwestią jest pozycja wartości prorodzinnych w kontekście innych wartości życia codziennego. Socjologowie wskazują na zmianę wartości i ich hierarchizacji we współczesnych społeczeństwach pluralistycznych. Dokonujące się przemiany zaznaczają się we wszystkich dziedzinach życia społecznego i indywidualnego, a więc w rodzinie, w pracy zawodowej, w polityce, kulturze, moralności i religii. Niekiedy określa się je jako kryzys kultury, a nawet traktuje jako zanikanie wartości i norm (anomia społeczno-moralna). Zwłaszcza wartości o charakterze konkretnym i instrumentalnym (wartości codzienne), podlegają szybkim procesom przemian, znacznie powolniejsze są one w przypadku wartości podstawowych i ostatecznych. Przekształcenia w wartościach i normach oddziałują na całe systemy normatywne, także te, które kształtują się w rodzinie ${ }^{13}$.

11 A. Sułek, Wartości życiowe dwóch pokoleń, [w:] Ciągłość i zmiana tradycji kulturowej, red. S. Nowak, PWN, Warszawa 1989, s. 293.

12 P. Sztompka, Autonomia - fundament kultury akademickiej, „Nauka” 2017, nr 3, s. 8.

13 R. Boguszewski, Religijność i moralność w społeczeństwie polskim: zależność czy autonomia? Studium socjologiczne, Wydawnictwo Adam Marszałek, Toruń 2012, s. 176-188. 
W latach dziewięćdziesiątych ubiegłego wieku dokonywały się zmiany w wartościach życiowych młodzieży. Według niektórych badań socjologicznych cele i dążenia życiowe w okresie transformacji ustrojowej

koncentrowały się wokół dwóch problemów: atrakcyjności pracy zawodowej i wartości życia rodzinnego. Do najważniejszych celów najczęściej zaliczano zdobycie ciekawej pracy, zgodnie z zainteresowaniami. Wartość stanowiło także udane i szczęśliwe życie rodzinne - wcześniej te dwa elementy dążeń młodego człowieka występowały w odwrotnej kolejności. Zmiana ta może być spowodowana tym, że obecnie dobra, ciekawa praca stała się wartością nie mniej istotną niż rodzina, bo jest o nią trudniej, tak samo jak wiele trzeba włożyć wysiłku w to, aby rodzina funkcjonowała prawidłowo i stwarzała warunki do realizacji potrzeb wszystkim jej członkom ${ }^{14}$.

Część sondaży opinii publicznej wskazuje, że w dalszym ciągu w hierarchii celów i dążeń życiowych nie ma wartości bardziej cennej niż rodzina. Inne sondaże dowodzą, że zaznacza się obecnie szybki awans wartości ekonomicznych związanych z dążeniem do podniesienia poziomu życia, znalezieniem dobrej pracy, zdobyciem wykształcenia itp. Zwłaszcza młodzież umieszcza wysoko w hierarchii celów i dążeń życiowych zdobycie wykształcenia i znalezienie pracy ${ }^{15}$. Wyróżnione w referowanych badaniach wartości codzienne, stanowiące przedmiot aspiracji i dążeń życiowych, obejmują tylko część złożonego zespołu wartości rzeczywiście uznawanych przez młodzież maturalną. Spośród wielu wartości życia codziennego respondenci mogli wybrać najwyżej pięć.

W całej zbiorowości maturzystów puławskich wybierano jako najważniejsze w życiu następujące wartości: dobrobyt - 32,5\%, sława - 5,9\%, władza - 4,9\%, spokojne życie - 46,5\%, dużo przygód - 30,4\%, silny charakter - 36,0\%, szczęście rodzinne - 69,9\%, ciekawa praca - 34,6\%, szacunek ludzki - 51,0\%, wiara religijna - 29,7\%, grono przyjaciół - 43,7\%, świadomość bycia potrzebnym innym ludziom - 38,1\%, pomyślność ojczyzny - 15,7\%, spokój w narodzie - $26,9 \%$, wielka, odwzajemniona miłość - 58,7\%, pomaganie innym ludziom - 33,6\%, wykształcenie - 24,5\%, inne wartości - 1,4\%, brak odpowiedzi - 0,7\% ${ }^{16}$.

14 R. Pawłowska, E. Jundziłł, Aspiracje życiowe wspótczesnej młodzieży licealnej w aspekcie przemian ustrojowych i środowiska rodzinnego, [w:] Polska młodzież - zaburzenia, zagrożenia w aktualnej rzeczywistości społecznej, red. T. Sołtysiak, M. Karwowska, Wydawnictwo Uczelniane Akademii Bydgoskiej, Bydgoszcz 2001, s. 221.

15 P. Długosz, Młodzież w dobie transformacji, [w:] Podkarpacie w procesie transformacji na przykładzie powiatu ropczycko-sędziszowskiego, red. B. Blachnicki, Wyższa Szkoła Społeczno-Gospodarcza w Tyczynie, Tyczyn 2002, s. 174.

16 K. Skoczylas, Wartości religijno-moralne młodzieży ponadgimnazjalnej Kujaw wschodnich, Wydawnictwo Duszpasterstwa Rolników, Włocławek 2016, s. 97-100; W. Janocha, Religijność osób niepetnosprawnych i ich rodzin. Studium socjologiczno-pastoralne, Wydawnictwo KUL, Lublin 2011; A. Kasperek, Poczucie sensu w życiu młodzieży akademickiej. Porównanie wyników z badań z lat 1988, 1998, 2005 i 2017, [w:] Między konstrukcją a dekonstrukcja uniwersum znaczeń. Badania religijności młodzieży akademickiej w latach 1988-1998-2005-2017, red. S. H. Zaręba, M. Zarzecki, Warszawskie Wydawnictwo Socjologiczne, Warszawa 2018, s. 60-63. 
Naczelna wartość życia codziennego, jaką jest szczęście rodzinne, utrzymała swoją pozycję w hierarchii uznawanych wartości, mimo niewielkiego spadku aprobaty. Spadek ten jest znacznie większy, jeżeli porównamy ogólną ocenę rodziny według kategorii „bardzo ważne” i „raczej ważne” (93,4\%), z oceną szczęścia rodzinnego i jego znaczenia w kontekście innych wartości życia codziennego (69,9\%). Prawdopodobnie wartość rodziny jeszcze bardziej uległaby pomniejszeniu, gdybyśmy zestawili ją alternatywnie $\mathrm{z}$ innymi konkurencyjnymi wartościami, jak np. rodzina a wykształcenie, rodzina a praca, rodzina a kariera zawodowa, rodzina a wolność. Jak wynika z niektórych badań socjologicznych, wśród dorosłej ludności, a zwłaszcza wśród młodzieży, w warunkach transformacji ustrojowej wzrasta znaczenie pracy zawodowej, kariery życiowej oraz wykształcenia. Nacisk na ambicje i przedsiębiorczość sprawia, że kwalifikacje zawodowe i wykształcenie stają się ważnym czynnikiem sukcesu życiowego. W zbiorowości młodzieży maturalnej wartości praca i wykształcenie nie zyskały na znaczeniu i nie oddziałały konkurencyjnie na wartość szczęścia rodzinnego. Być może młodzież ceni pracę i wykształcenie jako wartości instrumentalne, a stąd nieczęsto umieszcza je wśród najważniejszych celów i dążeń życiowych, o charakterze naczelnym.

Wśród wielu celów i dążeń życiowych naczelne miejsce przypada rodzinie. Wartość „szczęśliwe życie rodzinne”, skupiająca na sobie najwięcej wyborów, zajmuje zdecydowanie pierwszą pozycję wśród ocenianych wartości, które lokują się niżej na szczeblach drabiny hierarchicznej wartości. Być może udane życie rodzinne jest nie tylko traktowane jako wartość autonomiczna, ale i jako wartość instrumentalna. W tym drugim przypadku rodzina byłaby nie tylko zabezpieczeniem życiowym, ale i formą ucieczki przed niebezpieczeństwami zagrażającego świata.

Drugi blok wartości życiowych młodzieży maturalnej tworzą: wielka odwzajemniona miłość, szacunek ludzki, grono przyjaciół, spokojne życie, ciekawa praca, silny charakter, świadomość, że jest się potrzebnym innym ludziom, dobrobyt (powyżej 30\% akceptacji). Zwłaszcza wartość ,,wielka odwzajemniona miłość” zaznacza się u przeszło połowy badanych maturzystów. Te dwie wartości - rodzina i miłość - zwane przez badaczy wartościami afiliacyjnymi, wyrażającymi pragnienie przynależenia do małych grup społecznych, dominują nad pozostałymi celami i dążeniami życiowymi. Wartości znajdujące się na kolejnych miejscach dzieli niewielki dystans, mogą więc one zmieniać swoje miejsce w strukturze uznawanych wartości ${ }^{17}$.

${ }_{17}$ K. Szafraniec, Młodzi 2011, Kancelaria Prezesa Rady Ministrów, Warszawa 2011, s. 39-43; O. Štefaňak, Wartości moralne maturzystów słowackich. Na przykładzie diecezji spiskiej, Wydawnictwo Norbertinum, Lublin 2013, s. 152-164. 
Nie wydaje się, by na podstawie prostego zsumowania liczby wyborów można było wnioskować o rzeczywistym systemie wartości młodzieży szkolnej. System wartości to nie tylko zbiór pojedynczych wartości, ale i pewien sposób ich wzajemnego podporządkowania i powiązania. Może on mieć charakter układu hierarchicznego pionowego lub mieszanego (pionowego i poziomego). W pierwszym przypadku jakaś wartość dominuje nad pozostałymi i dla niej jednostka jest gotowa poświęcić wiele innych wartości. W drugim przypadku wybory wartości są uzależnione od sytuacji i okoliczności - w praktyce nie zaznacza się nadrzędność jednej wartości, wszystkie są traktowane niemal równorzędnie. Częstość dokonywanych wyborów pozwala na określenie pozycji poszczególnych celów i dążeń w hierarchii wartości, tych pierwszych i tych drugorzędnych w normatywnej wizji uznawanych wartości. Zapytaliśmy więc respondentów o wartości „najważniejsze z ważnych”.

W całej zbiorowości maturzystów puławskich w roku 2016 3,1\% badanych wybrało dobrobyt jako najważniejszą z ważnych wartości codziennych, 0,7\% - sławę, 0,4\% - władzę, 6,3\% - spokojne życie, 0,7\% - dużo przygód, 3,5\% - silny charakter, 33,2\% - szczęście rodzinne, 1,0\% - ciekawą pracę, 2,4\% - szacunek ludzi, 3,5\% - wiarę religijną, 5,9\% - grono przyjaciół, 4,5\% - świadomość bycia potrzebnym innym ludziom, 0,7\% - pomyślność ojczyzny, 1,0\% - spokój w narodzie, 14,0\% - wielką odwzajemnioną miłość, 3,8\% - pomaganie innym, 2,1\% - wykształcenie, 0,3\% - inne wartości, 12,9\% - brak odpowiedzi. Wybierane wartości są więc niezwykle rozproszone.

Liczba celów zaakceptowanych jako najważniejsze wskazuje na ogromy rozrzut opinii i poglądów co do znaczenia poszczególnych wartości życiowych. Pojawiają się wszystkie możliwe wybory, od najwyżej do najniżej cenionych. Wśród wartości uznawanych za priorytetowe pierwsze miejsce zajmuje szczęście rodzinne, chociaż nie w tak zdecydowany sposób, jak w wyborach wielokrotnych, na drugim miejscu uplasowała się wielka odwzajemniona miłość, na trzecim - spokojne życie, na czwartym - świadomość, że jest się potrzebnym innym ludziom, na piątym - wiara religijna, na szóstym - dobrobyt. Pozostałe wartości koncentrowały wokół siebie mniej niż po 4\% dokonywanych wyborów, przy dominacji dwóch wartości afiliacyjnych. Inne wartości uległy wyraźnemu rozproszeniu, a niektóre są odczuwane niemal śladowo ${ }^{18}$.

W analizie statystyczno-korelacyjnej bierzemy pod uwagę dwie wartości: rodzinę oraz wielką i odwzajemnioną miłość. Kobiety częściej niż mężczyźni preferują szczęśliwe życie rodzinne (41,1 wobec 22,0\%), młodzież licealna robi to rzadziej niż młodzież z tech-

18 E. Budzyńska, Ład moralny w zmieniającym się społeczeństwie. Studium socjologiczne wartości moralnych mieszkańców Katowic, Wydawnictwo UŚ, Katowice 2007, s. 141-152. 
ników (29,0 wobec 37,2\%), młodzież ze wsi i z małych miast częściej niż młodzież z Puław (38,4 wobec 24,8\%), młodzież wierząca częściej niż niewierząca (40,1 wobec 18,5\%), młodzież systematycznie praktykująca częściej niż w ogóle niepraktykująca (43,4 wobec 16,7\%). Wartość miłości jest częściej akceptowana przez kobiety niż mężczyzn (14,3 wobec 13,6\%), młodzież z liceów ogólnokształcących skłania się ku temu rzadziej niż ta z techników (11,6 wobec 16,2\%), młodzież ze wsi i małych miast częściej niż młodzież z Puław (16,4 wobec $10,1 \%)$, młodzież wierząca częściej niż niewierząca (20,8 wobec $3,7 \%)$, młodzież regularnie praktykująca częściej niż w ogóle niepraktykująca $(17,4$ wobec $7,4 \%)$.

W systemie wartości „najważniejszych z ważnych” mamy do czynienia ze swoistą mozaiką celów i dążeń życiowych. Dla części młodzieży ważne jest szczęście rodzinne i wielka miłość, dla innej części dobrobyt materialny i urozmaicone przygodami życie, dla jeszcze innej - szacunek ludzi, świadomość pomagania innym, życie religijne. Ogromny rozrzut opinii na temat wartości naczelnych w życiu każe wątpić w ukształtowany jednolity etos młodzieży szkolnej na poziomie najważniejszych celów w życiu. Należy zarazem podkreślić, że co ósmy badany maturzysta nie potrafił dokonać wyboru wartości „najważniejszych z ważnych”, co także pozwala zakładać słabe rozeznanie celów najważniejszych w życiu.

Analizy statystyczno-korelacyjne nie wykazały bardziej znaczących różnic w uznawanych wartościach codziennych ze względu na płeć badanych, typ szkoły i miejsce zamieszkania. Bardziej różnicująco oddziaływała zmienna niezależna „postawy wobec religii”. Cechy demograficzne i społeczne wpływały różnicująco tylko na kilka deklarowanych celów i dążeń życiowych: dobrobyt, szczęście rodzinne, wielka odwzajemniona miłość, spokojne życie i bycie pożytecznym dla innych. Różnice procentowe nie były jednak zbyt znaczące. Priorytetowe znaczenie rodziny we wszystkich kategoriach demograficznych i społecznych dowodzi, że nie mamy tu do czynienia z jakąś dekompozycją wartości codziennych, zmiana nie przeważa nad ciągłością wartości prorodzinnych ${ }^{19}$.

Do wartości wiodących należą bez wątpienia rodzina, miłość i przyjaźń. Do wartości wspierających, stanowiących jakby swoiste zaplecze dla tych pierwszych, trzeba zaliczyć pracę, wykształcenie, samorealizację, do pewnego stopnia także religię. Wyraźnie mniejszą popularnością cieszą się wartości o charakterze społecznym, wymagające bezinteresownego otwarcia się na sprawy i problemy konkretnego człowieka, a zwłaszcza na

\footnotetext{
J. Bartkowski, Wartości materialistyczne i postmaterialistyczne w Polsce w ujęciu porównawczym, [w:] Wartości, polityka, społeczeństwo, red. M. Zahorska, E. Nasalska, Wydawnictwo Naukowe SCHOLAR, Warszawa 2009, s. 33-47. Wyniki badania „Aktualne problemy i wydarzenia” (nr 276). Komunikat z badań CBOS (do użytku wewnętrznego), Warszawa 2013, s. 32.
} 
szersze struktury społeczne, takie jak np. ojczyzna. Od dawna utrzymuje się niska ranga wartości politycznych, co zapewne związane jest z brakiem zaufania do elit politycznych. Wiele wskazuje na to, że badani maturzyści są skoncentrowani na swoich potrzebach, do pewnego stopnia kształtuje się u nich orientacja na własne ,,ja”. Niezależnie od jakości deklarowanych przez maturzystów wartości życiowych trzeba podkreślić, że nie jest to pokolenie zawieszone w próżni aksjologicznej, ale jest zróżnicowane pod względem uznawanych wartości. Mimo pojawiających się wielu podobieństw w sferze wartości, jest wątpliwe, czy uznawane przez jednostki wartości prowadzą do wytwarzania się silniejszej grupowej czy pokoleniowej więzi ${ }^{20}$.

\section{WARTOŚCI PODSTAWOWE W ŚWIADOMOŚCI MŁODZIEŻY MATURALNEJ}

W życiu społecznym funkcjonują wartości, które przez większość obywateli są uznawane za mało ważne, są też takie, które w pewnych środowiskach społecznych są traktowane jako antywartości, w innych zaś są przyjmowane bez zastrzeżeń. Istnieją jednak wartości wspólne, uznawane niemal przez wszystkich. Są to wartości, bez których nie mogłoby istnieć społeczeństwo, czyli tzw. wartości podstawowe. Wartości podstawowe są źródłem kryteriów ocen w rozeznaniu rzeczywistości. Chodzi o takie dobra, które czynią życie ludzkie cennym i godnym. Nietykalny porządek wartości podstawowych powinien być respektowany w warunkach szybkich zmian społecznych, on także jest gwarantem tożsamości państwa prawa. W odróżnieniu od wartości ostatecznych, których poszukują jednostki, wartości podstawowe mają przede wszystkim wymiar społeczny, połączony niekiedy z kontekstem instytucjonalnym. Tworzą one w świadomości ludzkiej zasadnicze elementy i podstawy społeczeństwa obywatelskiego, są ważne zarówno dla społeczeństwa, jak i państwa ${ }^{21}$.

\section{Przez wartości podstawowe rozumie się}

mniejszy lub większy wachlarz wartości uświadamianych i akceptowanych przez wszystkich, lub przynajmniej przez większość członków społeczności, w oparciu o które dochodzą oni do consensusu (kompromisu), dialogu oraz podejmują pozytywną kooperację dla dobra wspólnego ${ }^{22}$.

\footnotetext{
20 M. Zemło, Wartości i normy uczniów szkót ponadpodstawowych białostockich placówek, [w:] Styl życia młodzieży Białegostoku. Raport, red. J. Mantura, Centrum Kształcenia Ustawicznego w Białymstoku, Białystok 2016, s. 69-74.

21 J. Höffner, Kirche in der Welt, Hrsg. U. Nothelle-Wildfeuer, J. Althammer, Verlag Ferdinand Schőningh, Paderborn 2018 , s. 229-238; J. Mariański, Wartości podstawowe gwarancją kultury moralnej społeczeństwa, [w:] Kultura a rynek, t. 1, red. S. Partycki, Wydawnictwo KUL, Lublin 2008, s. 22-33.

22 W. Piwowarski, ABC katolickiej nauki społecznej..., s. 75.
} 
Dostarczają one motywacji i legitymizacji dla podejmowanych decyzji i działań w skali społecznej, tworzą etyczne podstawy tożsamości różnych społeczności, inspirują do wspólnego działania na rzecz wszystkich obywateli. Są nazywane niekiedy wartościami ogólnoludzkimi, uniwersalnymi, niezbywalnymi, jednoczącymi, nienegocjowanymi i obywatelskimi.

Z innego punktu widzenia wartości podstawowe traktuje się jako absolutne ideały i normatywny etos łączący wszystkie siły społeczne i grupy interesu dla realizacji dobra wspólnego. Jako wartości o charakterze uniwersalnym zachowują one swoje znaczenie niezależnie od miejsca i czasu, od nich zależy normalne funkcjonowanie struktur społecznych ${ }^{23}$. Wartości podstawowe jako ogólne reguły społeczne obowiązują we wszystkich kulturach i zawsze, nawet jeżeli były i są wyrażane rozmaicie w konkretnych formach życia społecznego. Mają charakter moralny, a ich moc normatywna nie może być odczytywana wyłącznie z rzeczywistości jako indukcyjna norma moralna. Walor normatywny wartości podstawowych nie może być negocjowany, on po prostu istnieje.

Zakładamy, że młodzież maturalna w drugiej dekadzie wieku XXI odznacza się wysokim stopniem uświadomienia podstawowych wartości i to niezależnie od charakteru środowiska społecznego, nawet jeżeli w mniejszym stopniu dostrzega ich zastosowanie w życiu społecznym kraju. Stan realizacji wartości podstawowych odzwierciedla jedynie sytuację, jaką postrzega badana przez nas młodzież maturalna. Można przypuszczać, że zaznaczą się wyraźne różnice między powinnościowym i faktycznym stanem akceptacji podstawowych wartości społeczeństwa polskiego oraz pewne różnice w stosunku maturzystów do wartości podstawowych ze względu na cechy demograficzne, społeczne i religijne.

W kwestionariuszu ankiety skonstruowano dwa pytana operacjonalizujące wartości podstawowe (realizowane i postulowane), pozostawiając respondentom możliwość innych wyborów, nieprzewidzianych w kafeterii pytań. Wybrane wartości są rozpatrywane w podwójnym wymiarze: jako wartości, które są faktycznie uznawane w społeczeństwie oraz te, które powinny być uznawane. Jedne z nich mogą być niedocenione i przez to uzyskują niższe wskaźniki aprobaty (np. równość społeczna, sprawiedliwość społeczna, prawda), inne zaś - przeciwnie - są nadmiernie doceniane i przez to uzyskują wyższe wskaźniki (np. religia).

${ }_{23}$ K. Ryczan, Wartości katolików a typ środowiska miejskiego, Redakcja Wydawnictw KUL, Lublin 1992, s. 180. 
Wśród wartości podstawowych uznawanych w społeczeństwie polskim w opinii młodzieży wymieniano następujące wartości według malejącej częstotliwości wyborów: patriotyzm - 63,3\%, religia - 59,1\%, wolność - 57,3\%, demokracja - 56,3\%, prawa człowieka - 53,8\%, godność osoby ludzkiej - 37,1\%, solidarność - 36,4\%, prawda - 28,7\%, ideały socjalistyczne - 26,9\%, równość społeczna - 23,1\%, sprawiedliwość społeczna - 22,7\%. Tylko nieliczni ankietowani wskazywali na inne wartości $(0,3 \%)$ lub byli niezdecydowani w swoich wyborach $(1,4 \%)$. Wskaźnik przeciętny dla jedenastu ocenianych sytuacji funkcjonujących wartości podstawowych w społeczeństwie polskim wynosił w roku $2016-42,3 \%{ }^{24}$.

Podobne wyniki uzyskano w roku szkolnym 2009/2010 wśród maturzystów lubelskich: patriotyzm $-44,1 \%$, religia $-51,7 \%$, prawda - 16,6\%, wolność - 73,1\%, demokracja - 72,3\%, sprawiedliwość społeczna - 16,1\%, równość społeczna $-21,2 \%$, godność osoby ludzkiej - 37,5\%, prawa człowieka - 58,1\%, solidarność społeczna - 38,4\%, idee socjalistyczne - 32,1\% ${ }^{25}$; w roku 2005 zaś w Lublinie (odpowiednio) - 37,6\%, 54,2\%, 19,1\%, $64,8 \%, 60,5 \%, 11,6 \%, 13,7 \%, 27,9 \%, 46,4 \%, 34,0 \%, 28,6 \%$ (badania socjologiczne Emilii Żerel). Wskaźnik przeciętny wartości podstawowych uznanych za obecne w społeczeństwie polskim kształtował się w roku 2005 na poziomie 36,2\%, a w roku 2010 - 41,9\%.

Biorąc pod uwagę wartości faktycznie funkcjonujące w społeczeństwie w ocenie badanych maturzystów w roku 2016, nie dostrzega się znaczących różnic w deklarowanych opiniach kobiet i mężczyzn. Mężczyźni nieco częściej akcentowali patriotyzm (różnica 6,2\%), religię (różnica 6,2\%), solidarność (różnica 10,3\%) i ideały socjalistyczne (różnica $(6,1 \%)$, kobiety zaś nieco częściej wskazywały na wolność (różnica 8,2\%). W odniesieniu do pozostałych wartości funkcjonujących w społeczeństwie różnice były minimalne i sytuowały się poniżej granicy 4\%. Można by więc mówić o znaczącej zbieżności poglądów kobiet i mężczyzn w omawianej sprawie (według wskaźnika zbiorczego: kobiety - 41,3\%, mężczyźni - 43,6\%).

Niewielkie różnice występują w podkreślaniu wartości podstawowych między maturzystami uczęszczającymi do różnych typów szkół. Młodzież licealna nieco częściej akcentowała: demokrację (różnica 4,6\%), równość społeczną (różnica 7,2\%), godność osoby ludzkiej (różnica 4,1\%) i prawa człowieka (różnica 15,0\%), młodzież z techników

\footnotetext{
24 J. Mariański, Wartości podstawowe w świadomości młodzieży maturalnej, [w:] Godność osoby ludzkiej w społeczeństwie i gospodarce. Księga pamiątkowa ku czci śp. Księdza Profesora Franciszka J. Mazurka, red. S. Fel, M. Wódka, Wydawnictwo KUL, Lublin 2014, s. 242-248.

25 M. Rola, Wartości moralne w świadomości maturzystów..., s. 317.
} 
- patriotyzm (różnica 17,3\%), religię (różnica 20,3\%), prawdę (różnica 16,2\%) i ideały socjalistyczne (różnica 4,5\%). W odniesieniu do pozostałych wartości częstotliwość wskazań była bardzo zbliżona. Wskaźnik zbiorczy odnoszący się do młodzieży z liceów ogólnokształcących wynosił 40,6\%, do młodzieży z techników - 43,7\%. Także hierarchia wartości podstawowych była niemal identyczna w obydwu typach szkół.

Pochodzenie środowiskowe tylko nieznacznie różnicowało stosunek młodzieży maturalnej do wartości podstawowych. Młodzież ze wsi i z małych miast nieco częściej wskazywała na patriotyzm (różnica 8,9\%), religię (różnica 5,0\%) i solidarność (różnica 6,9\%), młodzież z Puław nieco częściej wybierała prawa człowieka (różnica 7,9\%). W odniesieniu do pozostałych wartości różnice wskaźników nie przekraczały 4\%. Można więc mówić o znacznym podobieństwie poglądów młodzieży pochodzącej ze wsi i małych miast oraz z Puław. Potwierdza tę konstatację także wskaźnik zbiorczy (41,9\% wobec $41,5 \%)$.

Zmienna niezależna „stosunek do wiary” nieznacznie różnicuje poglądy badanych maturzystów na temat wartości podstawowych. Respondenci deklarujący się jako wierzący częściej niż niewierzący wskazywali na wolność (różnica 24,6\%), niewierzący częściej dostrzegali religię (różnica 19,0\%), demokrację (różnica 7,6\%), równość społeczną (różnica $7,0 \%$ ), godność osoby ludzkiej (różnica 4,3\%), prawa człowieka (różnica 11,3\%) i ideały socjalistyczne (różnica 15,3\%). W odniesieniu do pozostałych wartości różnice wskaźników nie przekraczały 4 punktów procentowych. Wskaźnik zbiorczy kształtował się następująco: wierzący $-43,5 \%$, niezdecydowani w sprawach wiary $-47,0 \%$, obojętni religijnie $-25,2 \%$, niewierzący - 47,5\%. Niewierzący nieco częściej niż przedstawiciele pozostałych kategorii autoidentyfikacji religijnych dostrzegali funkcjonowanie wartości podstawowych w społeczeństwie, obojętni religijnie bardzo często nie wypowiadali się na ten temat.

Uczęszczający do kościoła w każdą niedzielę częściej niż w ogóle niepraktykujący wybierali wartości: patriotyzm (różnica 9,5\%), prawda (różnica 19,6\%), wolność (różnica 10,0\%), demokracja (różnica 6,7\%), sprawiedliwość społeczna (różnica 11,9\%), równość społeczna (różnica 7,2\%), prawa człowieka (różnica 5,2\%) i solidarność (różnica 11,4\%). W ogóle niepraktykujący częściej dostrzegali funkcjonowanie w społeczeństwie takich wartości, jak: religia (różnica 5,6\%) i ideały socjalistyczne (różnica 7,6\%). Wskaźnik zbiorczy wynosił dla uczęszczających regularnie do kościoła - 43,9\%, dla robiących to jeden lub trzy razy w miesiącu - 42,2\%, raz w miesiącu lub kilka razy w roku $-42,1 \%$ i dla w ogóle niepraktykujących $-37,4 \%$. Pełna absencja w praktykach religijnych nie sprzyja dostrzeganiu funkcjonowania wartości podstawowych w społeczeństwie polskim. 
Wachlarz uświadamianych wartości podstawowych funkcjonujących w społeczeństwie polskim jest zróżnicowany w ocenie badanych maturzystów puławskich. W roku 2016 najczęściej były dostrzegane dwie wartości podstawowe: patriotyzm i religia, nieco rzadziej wolność, demokracja i prawa człowieka. Uderzająco niska jest pozycja takich wartości, jak sprawiedliwość społeczna, równość społeczna i prawda. Jak wynika z przeprowadzonych analiz statystyczno-korelacyjnych, cechy demograficzne i społeczne, a nawet religijne, słabo różnicują badaną populację maturzystów w odniesieniu do faktycznie funkcjonujących w społeczeństwie polskim wartości podstawowych. Wierzący rzadziej niż niewierzący dostrzegają funkcjonowanie wartości religijnych w społeczeństwie. Wypowiadane przez maturzystów oceny dotyczące realizacji wartości podstawowych w społeczeństwie dowodzą ich znacznego deficytu ${ }^{26}$.

Uzyskane w referowanych badaniach socjologicznych wyniki empiryczne wskazują na fakt, że młodzież polska jest świadoma niedociągnięć w zakresie uznawania, a tym bardziej realizacji wartości podstawowych głoszonych przez system społeczno-polityczny. Nie znaczy to, że nie jest ona świadoma tego, jakie powinny być podstawowe wartości społeczeństwa polskiego. W procesie transformacji ustrojowej dochodzi do konfliktów interpretacyjnych w odniesieniu do wartości podstawowych. Znajdują się one niekiedy w polu polemik ideologicznych. Zgadzamy się w odniesieniu do wartości najważniejszych, ale różnimy się co do sposobu ich konkretyzacji. Wartości podstawowe zmieniają się powoli, stąd wobec nich zaznacza się znaczny konsens międzypokoleniowy. Bez ich porządkującej i stabilizującej roli życie w społeczeństwie byłoby praktycznie niemożliwe.

W przeprowadzonych badaniach ankietowych zapytano młodzież o wartości postulowane, czyli te, które powinny być szczególnie akcentowane w społeczeństwie polskim. O ile uprzednio młodzież wypowiadała swoje opinie na temat, $\mathrm{w}$ jakim stopniu przedłożony jej do oceny zestaw wartości podstawowych jest uznawany w społeczeństwie, to obecnie - w jakim stopniu powinien być on uznawany przynajmniej przez większość społeczeństwa (wartości podstawowe wymagające uznania). Dość pesymistyczny pogląd młodzieży na temat realizacji wartości podstawowych w społeczeństwie polskim nie oznacza, że jest ona nieświadoma, jakie wartości podstawowe powinny być obecne w społeczeństwie polskim. Wartości te tworzą tzw. orientację normatywną społeczeństwa, pośrednio pozwalają sprecyzować oczekiwania młodych Polaków dotyczące wartości podstawowych.

26 A. Ochocki, Naród i wartości, [w:] Między konstrukcją a dekonstrukcją uniwersum znaczeń. Badania religijności młodzieży akademickiej w latach 1988-1998-2005-2017, red. S. H. Zaręba, M. Zarzecki, Warszawskie Wydawnictwo Socjologiczne, Warszawa 2018, s. 278-279. 
W całej zbiorowości maturzystów puławskich postulowano następujące wartości podstawowe w życiu społecznym: sprawiedliwość społeczna - 78,2\%, równość społeczna - 76,6\%, prawda - 70,6\%, godność osoby ludzkiej - 61,5\%, solidarność - 57,1\%, ideały socjalistyczne $-44,8 \%$, prawa człowieka - 42,9\%, demokracja - 39,3\%, wolność - 38,9\%, patriotyzm - 31,7\%, religia - 31,7\%, „trudno powiedzieć” - 1,2\%. Część maturzystów wymieniła inne kwestie dodatkowe, które powinny być ważne w społeczeństwie (1,6\%). Szczególnie silnie postulowane są te wartości, które nie są realizowane - według opinii maturzystów - w społeczeństwie polskim (sprawiedliwość społeczna, równość społeczna, prawda i godność ludzka). Wskaźnik przeciętny postulowanych wartości podstawowych kształtował się na poziomie $52,1 \%{ }^{27}$.

Co do wolności, patriotyzmu i demokracji można hipotetycznie założyć, że badana młodzież dostrzega już w wystarczającym stopniu realizację tych wartości i nie odczuwa potrzeby ich zintensyfikowania. Stosunkowo wysoka jest aprobata ideałów socjalistycznych, na których przecież wielu Polaków się zawiodło. Trudniejszy do wyjaśnienia jest względnie niski wskaźnik religii jako wartości postulowanej. Można twierdzić, że młodzież ceni religię jako wartość kulturową i ogólnospołeczną, nie ceni zaś jej jako wartość osobową i przeżywaną ${ }^{28}$. Bardziej wiarygodna jest hipoteza wskazująca, że wartości religijne faktycznie straciły na znaczeniu w świadomości młodego pokolenia i dlatego nie postuluje się ich w szerszym zakresie jako wartości podstawowych. Pogląd „za dużo religii w społeczeństwie” może korespondować z utrwalonym w latach dziewięćdziesiątych przekonaniem, że Kościół katolicki ma zbyt wiele władzy i próbuje decydująco kształtować życie społeczne oraz że odgrywa zbyt dużą rolę w życiu politycznym kraju. Lokata wartości religijnych w hierarchii postulowanych wartości podstawowych zapowiada pewien kryzys świadomości religijnej ludzi młodych w naszym kraju.

W odniesieniu do postulowanych wartości podstawowych wymagających uznania w społeczeństwie polskim płeć badanych maturzystów nie odgrywa roli różnicującej. Przeciętny wskaźnik akceptacji tych wartości wynosi 53,4\% dla kobiet i 50,2\% dla mężczyzn. Kobiety nieco częściej niż mężczyźni akcentują patriotyzm (różnica 9,5\%), religię (różnica 6,2\%) i solidarność (różnica 11,8\%), mężczyźni są nieco bardziej wrażliwi na wartości związane z wolnością (różnica 7,5\%). Pozostałe wartości są postulowane jako

27 J. Mariański, Wartości podstawowe, [w:] Encyklopedia aksjologii pedagogicznej..., s. 1280-1284; S. H. Zaręba, Dynamika świadomości religijno-moralnej młodzieży w warunkach przemian ustrojowych w Polsce (1988-1998), Zakład Wydawnictw Statystycznych, Warszawa 2003, s. 177.

28 W. Piwowarski, Podstawowe wartości społeczeństwa polskiego, [w:] Liberalizm i katolicyzm dzisiaj, Friedrich-NaumannStiftung, Warszawa 1994, s. 7. 
ważne dla społeczeństwa w zbliżony sposób przez kobiety i mężczyzn. Kobiety nieco częściej zgłaszają postulaty ożywienia w wymiarach społecznych wartości tradycyjnych (patriotyzm, religia).

Wskaźniki aprobaty wartości podstawowych postulowanych w społeczeństwie przez młodzież maturalną z Puław są nieco zróżnicowane ze względu na typ szkoły. Potwierdza to przeciętny wskaźnik akceptacji: maturzyści z liceów ogólnokształcących - 49,9\%, maturzyści z techników - 54,2\% (różnica 4,3\%). Licealiści nieco częściej aprobują patriotyzm (różnica 12,0\%), religię (różnica 7,3\%) i prawdę (12,0\%), maturzyści z techników częściej wskazują demokrację (różnica 8,8\%), równość społeczną (różnica 12,2\%), prawa człowieka (różnica 20,5\%), sprawiedliwość społeczną (różnica 5,7\%) i godność osoby ludzkiej (różnica 5,4\%). Młodzież ze szkół technicznych nieco częściej aprobuje wartości podstawowe typowe dla nowoczesnych społeczeństw pluralistyczno-demokratycznych.

Pochodzenie terytorialne badanych maturzystów puławskich wnosi tylko nieznaczne zróżnicowania w akceptacji postulowanych wartości podstawowych. Wskaźnik przeciętny aprobaty tych wartości jest niemal identyczny wśród młodzieży pochodzącej ze wsi i z miast do 20 tys. mieszkańców (52,1\%), jak młodzieży mieszkającej w Puławach (52,8\%). Młodzież z mniejszych miejscowości częściej postulowała obecność w społeczeństwie polskim takich wartości, jak patriotyzm (różnica 9,3\%), religia (różnica 5,0\%) i prawa człowieka (różnica 6,0\%), natomiast młodzież z Puław częściej aprobowała prawdę (różnica 11,9\%), wolność (różnica 6,7\%) i godność osoby ludzkiej (różnica 5,6\%). $\mathrm{W}$ odniesieniu do pozostałych wartości podstawowych różnice wskaźników nie przekraczały 5\%, co wskazuje na zbliżone oceny zarówno wartości tradycyjnych, jak i nowoczesnych.

Postawy wobec religii nieznacznie różnicują oceny postulowanych wartości podstawowych. Przeciętny wskaźnik ustosunkowania się do nich kształtuje się na zbliżonym poziomie: wierzący - 51,9\%, niezdecydowani, ale przywiązani do tradycji religijnych - 50,0\%, obojętni religijnie - 55,3\%, niewierzący - 53,6\%. Wierzący częściej niż niewierzący postulowali wzrost obecności w społeczeństwie polskim takich wartości, jak religia (różnica 30,9\%) i prawa człowieka (różnica 6,1\%), niewierzący częściej wybierali wolność (różnica 32,8\%), sprawiedliwość społeczną (różnica 13,4\%), równość społeczną (różnica 8,1\%) i solidarność (różnica 6,8\%). W ogólnym wymiarze postawy wobec religii wywierają nieznaczny wpływ różnicujący na poziom akceptacji wartości podstawowych, chociaż wierzący są nieco bardziej wrażliwi na wartości tradycyjne, niewierzący zaś na 
niektóre wartości charakterystyczne dla społeczeństw demokratycznych. W odniesieniu do wartości religijnych zaznacza się regularny spadek aprobaty w miarę przechodzenia od kategorii osób wierzących do kategorii osób niewierzących.

Zmienna niezależna „praktyki religijne” nie różnicuje w skali globalnej wyboru wartości podstawowych postulowanych dla społeczeństwa. Według przeciętnego wskaźnika $53,3 \%$ badanych maturzystów praktykujących regularnie postulowało wzmocnienie wartości podstawowych, 51,9\% - w przypadku praktykujących jeden lub trzy razy w miesiącu, 51,6\% - praktykujących raz w miesiącu lub kilka razy w roku i 53,6\% - w ogóle niepraktykujących. Wybory postulowanych wartości podstawowych nie układały się w jakieś zależności przyczynowe. Jedynie w miarę przechodzenia od praktykujących regularnie do w ogóle niepraktykujących zmniejszały się wybory wartości religijnych (od 45,3 do 24,4\%).

Na nieco wyższy poziom aprobaty postulowanych wartości podstawowych wskazywały inne badania socjologiczne. W całej zbiorowości maturzystów lubelskich w roku szkolnym 2009/2010 postulowano następujące wartości podstawowe w życiu społecznym: prawda $-80,4 \%$, sprawiedliwość społeczna $-80,1 \%$, równość społeczna $-74,0 \%$, godność osoby ludzkiej - 60,1\%, solidarność - 54,6\%, patriotyzm - 53,9\%, religia - 44,3\%, prawa człowieka - 40,8\%, ideały socjalistyczne - 38,9\%, wolność - 25,6\%, demokracja - 23,8\%. Wskaźnik przeciętny postulowanych wartości kształtował się na poziomie $52,4 \%$. Szczególnie silnie sugerowane były te wartości, które nie były realizowane - według opinii respondentów - w społeczeństwie polskim, takie jak prawda, sprawiedliwość i równość społeczna ${ }^{29}$. Podobne wyniki uzyskała Emilia Żerel we wcześniejszych badaniach socjologicznych w Lublinie w roku 2005 (wskaźnik przeciętny $-57,0 \%)$.

Młodzież z regionu konińskiego postulowała następujące wartości podstawowe: patriotyzm - 34,4\%, religia - 48,1\%, prawda - 65,7\%, wolność - 52,7\%, demokracja - 33,3\%, sprawiedliwość społeczna - 61,6\%, równość społeczna - 79,2\%, godność osoby ludzkiej - 68,8\%, prawa człowieka - 51,6\%, solidarność - 52,8\%, idee socjalistyczne - 43,2\%. Wskaźnik przeciętny postulowanych wartości podstawowych wśród młodzieży $\mathrm{z}$ regionu konińskiego kształtował się na poziomie $54,2 \%{ }^{30}$.

29 M. Rola, Wartości moralne w świadomości maturzystów..., s. 320.

30 K. Skoczylas, Wartości młodych katolików regionu konińskiego. Studium katechetyczno-pastoralne na przykładzie wybranych szkół ponadgimnazjalnych regionu konińskiego, UMK, Toruń 2011, s. 450-451. 
Ogólnie mówiąc, badana młodzież maturalna w znacznym stopniu akceptuje wartości podstawowe społeczeństwa polskiego, co więcej domaga się ich uświadomienia i realizacji. Znacznie wyżej ceni perspektywę rozwoju wartości podstawowych niż stan ich realizacji w skali społecznej, czyli wartości te powinny według niej być realizowane w wyższym stopniu niż dotychczas. Cechy demograficzne i społeczne, choć wywierają pewien wpływ różnicujący w zakresie części wartości podstawowych uznanych lub postulowanych, to jednak ogólnie słabo różnicują badaną populację maturzystów. Związek korelacyjny zaznacza się jedynie w odniesieniu do niektórych wartości, jak religia, wolność i demokracja. Jest rzeczą charakterystyczną, że w postulatach ceni się zarówno wybrane wartości podstawowe z nowych ruchów społecznych (np. prawda, godność), jak i z tradycji narodu (np. patriotyzm), czy z nowych ruchów religijnych (np. równość społeczna) $)^{31}$.

Aprobata wartości podstawowych tkwi więc zarówno w przeszłości, jak i teraźniejszości. Spośród wymienionych wartości interesujące jest zwłaszcza domaganie się poszanowania prawdy, sprawiedliwości i równości społecznej, a więc tych wartości, które - według oceny badanych - charakteryzują się szczególnie niskim poziomem realizacji w społeczeństwie. Stosunkowo wysoka jest ranga ideałów socjalistycznych i to zarówno w ocenie wartości faktycznie uznawanych, jak i postulowanych. Dwie wartości akcentowane w tradycji socjalistycznej (sprawiedliwość i równość społeczna) są w dalszym ciągu bardzo silnie postulowane jako wartości podstawowe społeczeństwa polskiego. Dokonująca się w latach osiemdziesiątych ubiegłego wieku erozja zarówno uznania systemu socjalistycznego, jak i wielu istotnych elementów ideologii socjalistycznej nie doprowadziła do całkowitego wyrugowania ideałów socjalistycznych z życia społecznego.

\section{UWAGI KOŃCOWE}

Przeprowadzone badania socjologiczne wskazują, że ogólne wartości prorodzinne są jeszcze mocno zakorzenione w mentalności młodzieży maturalnej (wartości „mocne”). W okresie ponad 15 lat nie uległy one wyraźnym zmianom. Do wartości wiodących należy - obok rodziny - wielka odwzajemniona miłość i przyjaźń. Hierarchia wartości najważniejszych prowadzi więc przede wszystkim przez sferę prywatną i intymną młodego człowieka. Inne wartości, zwłaszcza te o charakterze społecznym, są podporządkowane

31 J. Mariański, Kondycja religijna i moralna młodzieży szkót średnich w latach 1988-1998-2005-2017 (raport z ogólnopolskich badań socjologicznych), Wydawnictwo Adam Marszałek, Toruń 2018, s. 357-358. 
w hierarchii ważności wartościom o charakterze indywidualnym. Wartości związane z prestiżem, zaangażowaniem społecznym, a także wartości polityczne, a nawet religijne, są oceniane znacznie niżej, zyskując do pewnego stopnia charakter wartości „,tolerowanych”. Koncentracja na własnej osobie, zapatrzenie się we własne sprawy i problemy, może być dowodem wzrostu procesów indywidualizacyjnych (ucieczka w prywatność) i poszukiwania bezpieczeństwa poprzez emocjonalne relacje z wąską grupą osób, przede wszystkim z rodziną. Wartości codzienne i egzystencjalne podlegają pewnym przemianom, ale nie ma „,twardych” dowodów na istnienie procesu dezaksjologizacji świadomości moralnej młodzieży polskiej ${ }^{32}$.

Ze społecznego punktu widzenia ważna jest problematyka wartości podstawowych. Uznawane wartości przybierają różne wymiary oraz ładunek emocjonalny i normatywny. Przeprowadzone analizy socjologiczne wyników badań nad maturzystami pozwalają stwierdzić, że młodzież ta relatywnie wysoko ceni wartości podstawowe w społeczeństwie, chociaż ma daleko idącą świadomość, że nie są one dostatecznie realizowane. W odniesieniu do niektórych wartości aprobata na płaszczyźnie faktycznego uznania jest wyższa niż na płaszczyźnie postulowanego uznania (religia, wolność, demokracja, prawa człowieka). W wymiarach ogólnych (według przeciętnego wskaźnika aprobaty) analizowane postulowane wartości podstawowe są silniej wyrażane przez badanych niż stwierdzenie faktu ich obecności w życiu społecznym. Jeżeli istnieje coś takiego jak minimalny i maksymalny konsens dotyczący wartości podstawowych, to badana młodzież maturalna znajduje się pośrodku między jednym i drugim biegunem.

Trudno byłoby utrzymywać tezę, że aksjologiczne zobojętnienie objęło dość rozległe obszary wartości podstawowych. We wszystkich środowiskach społecznych zaznacza się lekkie rozdwojenie pomiędzy faktycznym i normatywnym wymiarem postrzegania rzeczywistości społecznej poprzez pryzmat wartości podstawowych. Spośród wartości specyficznych dla narodu polskiego bardziej wyraźnie zaznacza się aprobata normatywna dla patriotyzmu, w nieco mniejszym zakresie dla religii. Wartości podstawowych nie można tylko posiadać, nie można ich „magazynować”. Trzeba je stale zdobywać i tworzyć. Świadomość wartości podstawowych powinna wzrastać, od uświadomienia sobie przez obywateli wartości podstawowych i ich urzeczywistnienia zależy bowiem organizacja i przyszłość polskiego społeczeństwa.

32 J. Mariański, Małżeństwo i rodzina w świadomości młodzieży maturalnej - stabilność i zmiana, Wydawnictwo Adam Marszałek, Toruń 2012, s. 323-351. 


\section{BIBLIOGRAFIA}

Bajkowski T., U źródeł tożsamości rodzinnej. System rodzinny w percepcji młodzieży akademickiej, Wydawnictwo Naukowe SCHOLAR, Warszawa 2018.

Bartkowski J., Wartości materialistyczne i postmaterialistyczne w Polsce w ujęciu porównawczym, [w:] Wartości, polityka, społeczeństwo, red. M. Zahorska, E. Nasalska, Wydawnictwo Naukowe SCHOLAR, Warszawa 2009.

Biernat T., Małżeństwo i rodzina w opiniach młodych Polaków, Niemców i Hiszpanów, „Kultura i Edukacja” $2009, \mathrm{nr} 2$.

Boguszewski R., Religijność i moralność w społeczeństwie polskim: zależność czy autonomia? Studium socjologiczne, Wydawnictwo Adam Marszałek, Toruń 2012.

Boguszewski R., Współczesne znaczenie i rozumienie rodziny w Polsce, „Zeszyty Naukowe KUL” 2015, nr 4 (58).

Budzyńska E., Ład moralny w zmieniającym się społeczeństwie. Studium socjologiczne wartości moralnych mieszkańców Katowic, UŚ, Katowice 2007.

Budzyńska E., Międzypokoleniowe więzi w rodzinie. Studium socjologiczne rodzin polskich i słowackich, UŚ, Katowice 2018 .

Długosz P., Młodzież $w$ dobie transformacji, [w:] Podkarpacie $w$ procesie transformacji na przykładzie powiatu ropczycko-sędziszowskiego, red. B. Blachnicki, Wyższa Szkoła Społeczno-Gospodarcza w Tyczynie, Tyczyn 2002.

Górny A., Religia i rodzina jako fundament świata wartości współczesnej rodziny śląskiej, [w:] Młodzi w społeczeństwie zmiany. Studia polsko-ukraińskie, red. M. Sroczyńska, J. Paczkowski, Wyższa Szkoła Umiejętności, Kielce 2010.

Hamachers-Zuba U., Lehner E., Tschipan C., Partnerschaft, Familie und Geschlechterverhältnisse in Österreich, [w:] Die Österreicher/-innen. Wertewandel 1990-2008, Hrsg. C. Friesl, U. Hamachers-Zuba, R. Polak, Czernin Verlag, Wien 2009.

Höffner J., Kirche in der Welt, Hrsg. U. Nothelle-Wildfeuer, J. Althammer, Verlag Ferdinand Schőningh, Paderborn 2018.

Janocha W., Religijność osób niepetnosprawnych i ich rodzin. Studium socjologiczno-pastoralne, Wydawnictwo KUL, Lublin 2011.

Kasperek A., Poczucie sensu w życiu młodzieży akademickiej. Porównanie wyników z badań z lat 1988, 1998, 2005 i 2017, [w:] Między konstrukcją a dekonstrukcją uniwersum znaczeń. Badania religijności młodzieży akademickiej w latach 1988-1998-2005-2017, red. S. H. Zaręba, M. Zarzecki, Warszawskie Wydawnictwo Socjologiczne, Warszawa 2018.

Mariański J., Kondycja religijna i moralna młodzieży szkół średnich w latach 1988-1998-2005-2017 (raport z ogólnopolskich badań socjologicznych), Wydawnictwo Adam Marszałek, Toruń 2018.

Mariański J., Małżeństwo i rodzina w świadomości młodzieży maturalnej - stabilność i zmiana, Wydawnictwo Adam Marszałek, Toruń 2012.

Mariański J., Religijność maturzystów puławskich w procesie przemian, „Zeszyty Naukowe KUL” 2017, nr 2 (60).

Mariański J., Wartości osobowe i społeczne, [w:] Encyklopedia aksjologii pedagogicznej, red. K. Chałas, A. Maj, POLWEN Polskie Wydawnictwo Encyklopedyczne, Radom 2016.

Mariański J., Wartości podstawowe, [w:] Encyklopedia aksjologii pedagogicznej, red. K. Chałas, A. Maj, POLWEN Polskie Wydawnictwo Encyklopedyczne, Radom 2016.

Mariański J., Wartości podstawowe gwarancją kultury moralnej społeczeństwa, [w:] Kultura a rynek, t. 1, red. S. Partycki, Wydawnictwo KUL, Lublin 2008.

Mariański J., Wartości podstawowe w świadomości młodzieży maturalnej, [w:] Godność osoby ludzkiej w społeczeństwie i gospodarce. Księga pamiątkowa ku czci śp. Księdza Profesora Franciszka J. Mazurka, red. S. Fel, M. Wódka, Wydawnictwo KUL, Lublin 2014. 
Ochocki A., Naród i wartości, [w:] Między konstrukcją a dekonstrukcją uniwersum znaczeń. Badania religijności młodzieży akademickiej w latach 1988-1998-2005-2017, red. S. H. Zaręba, M. Zarzecki, Warszawskie Wydawnictwo Socjologiczne, Warszawa 2018.

Pawłowska R., Jundziłł E., Aspiracje życiowe wspótczesnej młodzieży licealnej w aspekcie przemian ustrojowych i środowiska rodzinnego, [w:] Polska młodzież - zaburzenia, zagrożenia w aktualnej rzeczywistości społecznej, red. T. Sołtysiak, M. Karwowska, Wydawnictwo Uczelniane Akademii Bydgoskiej, Bydgoszcz 2001.

Piwowarski W., ABC katolickiej nauki społecznej, cz. I, Wprowadzenie, podstawy, kierunki, Wydawnictwo Diecezjalne, Pelplin 1993.

Piwowarski W., Podstawowe wartości społeczeństwa polskiego, [w:] Liberalizm i katolicyzm dzisiaj, Friedrich-Naumann-Stiftung, Warszawa 1994.

Rola M., Wartości moralne w świadomości maturzystów lubelskich. Studium socjologiczne, Drukarnia Standruk, Lublin 2016 .

Romanowicz W., Podstawowe wartości młodzieży prawosławnej, „Rozprawy Społeczne” 2014, nr 2 (8).

Ryczan K., Wartości katolików a typ środowiska miejskiego, Redakcja Wydawnictw KUL, Lublin 1992.

Skoczylas K., Wartości młodych katolików regionu konińskiego. Studium katechetyczno-pastoralne na przykładzie wybranych szkół ponadgimnazjalnych regionu konińskiego, UMK, Toruń 2011.

Skoczylas K., Wartości religijno-moralne młodzieży ponadgimnazjalnej Kujaw wschodnich, Wydawnictwo Duszpasterstwa Rolników, Włocławek 2016.

Spaemann R., Kroki poza siebie. Przemówienia i eseje, Oficyna Naukowa, Warszawa 2012.

Štefaňak O., Wartości moralne maturzystów słowackich. Na przykładzie diecezji spiskiej, Wydawnictwo Norbertinum, Lublin 2013.

Sułek A., Wartości życiowe dwóch pokoleń, [w:] Ciągłość i zmiana tradycji kulturowej, red. S. Nowak, PWN, Warszawa 1989 .

Szafraniec K., Młodość jako wyłaniający się problem i nowa polityczna siła, „Nauka” 2010, nr 1.

Szafraniec K., Młodzi 2011, Kancelaria Prezesa Rady Ministrów, Warszawa 2011.

Sztompka P., Autonomia - fundament kultury akademickiej, „Nauka” 2017, nr 3.

Szymczyk J., Przemiany wartości Polaków. Wybrane aspekty i tendencje, [w:] Społeczne i etyczne aspekty rozwoju społecznego, red. W. Jedynak, J. Kinal, URz, Rzeszów 2015.

Wójcik P., System wartości deklarowanych przez maturzystów liceów ogólnokształcących województwa warmińsko-mazurskiego w kontekście nauki Kościoła katolickiego. Informacja o badaniu, „Societas/Communitas” 2014, nr 1.

Wyniki badania „Aktualne problemy i wydarzenia” (nr 276). Komunikat z badań CBOS (do użytku wewnętrznego), Warszawa 2013, s. 32.

Zaręba S. H., Dynamika świadomości religijno-moralnej młodzieży w warunkach przemian ustrojowych $w$ Polsce (1988-1998), Zakład Wydawnictw Statystycznych, Warszawa 2003.

Zemło M., Wartości i normy uczniów szkół ponadpodstawowych białostockich placówek, [w:] Styl życia młodzieży Białegostoku. Raport, red. J. Mantura, Centrum Kształcenia Ustawicznego w Białymstoku, Białystok 2016. 